\title{
MLL/GPHN Fusion Gene
}

National Cancer Institute

\section{Source}

National Cancer Institute. MLL/GPHN Fusion Gene. NCI Thesaurus. Code C99331.

A fusion gene that results from a chromosomal translocation $t(11 ; 14)(q 23 ; q 24)$ which fuses exon 8 of the MLL gene to the 3' half of the GPHN gene. This rearrangement is associated with treatment-related acute undifferentiated leukemia. 